\author{
Renata Nesterowicz \\ Uniwersytet Rzeszowski, Polska - University of Rzeszów, Poland \\ Aleksandra Nesterowicz \\ Uniwersytet Rzeszowski, Polska - University of Rzeszów, Poland
}

\title{
Znaczenie leasingu jako źródła finansowania działalności i rozwoju przedsiębiorstw
}

\section{The Importance of Leasing as a Source of Financing the Activity and Development of Enterprises}

Streszczenie: Wiele podmiotów w trakcie rozpoczynania działalności oraz podczas jej prowadzenia poszukuje niezbędnego im do rozwoju kapitału. Jednym z najpopularniejszych źródeł zewnętrznego finansowania na rynku polskim i na rynku światowym jest leasing. Korzyści wynikające z finansowania działalności gospodarczej leasingiem sprawiły, iż na tę formę pozyskania kapitału decyduje się coraz większa liczba podmiotów zarówno w naszym kraju, jak i w całej Unii Europejskiej (UE). Struktura przedmiotowa branży leasingowej niezmiennie od lat zdominowana jest przez leasing samochodów osobowych, natomiast najmniej umów leasingowych dotyczy nieruchomości. Analizując strukturę rynku leasingu w Polsce, można dotrzeć do informacji, które pokazują proces wdrażania tej formy finansowania, jej rozwój na przełomie kilkudziesięciu lat, a także pozycję, na której rynek leasingu w naszym kraju uplasował się w rankingach światowych. Ważną cechą tego rodzaju finansowania jest to, że nie wpływa ono na ocenę zdolności kredytowej firmy, gdyż operacja leasingowa nie jest traktowana w bilansie jako zobowiązanie. Jednak w ostatnich miesiącach, jak donoszą publikacje Związku Polskiego Leasingu (ZPL), na rynku leasingu negatywnie odbiła się pandemia koronawirusa. Okazało się, iż leasingobiorcy od momentu ogłoszenia pierwszego przypadku zachorowania w Polsce zaczęli masowo rezygnować z rozpoczętych już rozmów na temat leasingu oraz wycofywać wnioski. Duża część korzystających z leasingu musiała nagle zawiesić swoją działalność gospodarczą. Według danych ZPL, marzec 2020 r. w porównaniu z marcem 2019 r. zapisał się blisko 32-procentowym spadkiem wartości rynku leasingu.

\begin{abstract}
Numerous entities, when starting and then running their business, look for the capital necessary for the development of the enterprise. One of the most popular sources of external financing, both on the Polish and global market, is leasing. Due to the benefits of financing business activities with leasing, an increasing number of entities both in our country and in the entire EU decide to obtain this form of capital. For years, the subject structure of the leasing industry has been invariably dominated by passenger car leasing, while real estate leasing contracts constitute the smallest share. By analysing the structure of the leasing market in Poland, one can find information that shows the process of implementing this form of financing, its development over the course of several decades, and the position on
\end{abstract}


which it ranked in world rankings. An important feature of this type of financing is that it does not affect the company's creditworthiness as the leasing operation is not treated as a liability in the balance sheet. According to the publications of the Polish Leasing Association (ZPL), the coronavirus also negatively affected the leasing market. It turned out that the lessees, from the moment the first case of falling ill in Poland was announced, began to resign from the already started talks on leasing and withdraw their applications. A large proportion of those using leasing suddenly had to suspend their business activities. According to ZPL data, March 2020, compared to March 2019, recorded a nearly $32 \%$ decrease in the value of the leasing market.

Słowa kluczowe: działalność gospodarcza; finansowanie; leasing

Keywords: economic activity; financing; leasing

Otrzymano: 29 maja 2020

Received: 29 May 2020

Zaakceptowano: 8 października 2020

Accepted: 8 October 2020

\section{Sugerowana cytacja/Suggested citation:}

Nestorowicz, R., Nestorowicz, A. (2020). Znaczenie leasingu jako źródła finansowania działalności i rozwoju przedsiębiorstw. Przedsiębiorczość - Edukacja [Entrepreneurship - Education], 16(2), 250-260. doi: 10.24917/20833296.162.20

\section{Wstęp}

Leasing w Polsce staje się usługą coraz bardziej znaną i coraz częściej wykorzystywaną w działalności przedsiębiorstw. O powszechnym zastosowaniu leasingu w naszym kraju można mówić jednak dopiero od 1989 r. Wcześniej umowy leasingowe zawierano sporadycznie. Pierwsze spółki leasingowe zaczęły pojawiać się z początkiem lat 90. Możliwość powoływania do życia firm leasingowych zaczęły rozpatrywać zarówno banki, jak i prywatne grupy kapitałowe. Szczególną motywacją do zakładania prywatnych firm leasingowych, tzw. libero, a więc nienależących do banków, było ustawowe zwolnienie z podatku dochodowego przez trzy lata wszystkich firm, w których znajdował się kapitał zagraniczny, czyli tzw. wówczas joint ventures.

Pierwsze efekty na rynku polskiego leasingu odnotowano w latach 1990-1993, po okresie łatwego dostępu do kredytów bankowych. Z powodu niemożności ich ściągnięcia, banki ograniczyły dostęp do kredytów za pomocą barier proceduralnych.

Jak wiadomo, prowadzenie działalności gospodarczej bez względu na jej charakter wiąże się z wydatkami i koniecznością ponoszenia kosztów. Wiele podmiotów podczas rozpoczynania działalności bądź w trakcie jej prowadzenia poszukuje kapitału niezbędnego im do rozwoju. Tak też jednym z najpopularniejszych źródeł zewnętrznego finansowania zarówno na rynku polskim, jak i na rynku światowym stał się leasing. Chociaż jego historia zaczęła się już w starożytności, to nadal uznawany jest on za największego konkurenta tradycyjnego kredytu bankowego. Podmioty, które z powodu niedostatecznej ilości kapitału poszukują różnych rozwiązań, często zwracają uwagę na finansowanie inwestycji leasingiem. Z uwagi na elastyczny charakter umów leasingowych, jak i na wielość form, z których można skorzystać, leasing może być źródłem pozyskania kapitału dla większości podmiotów gospodarczych. Korzystający z leasingu często decydują się na tę formę finansowania również ze względu na możliwość uzyskania stałych kosztów 
przedsiębiorstwa, co dają raty leasingowe. Swoją przewagę np. nad kredytem, który jest także często wykorzystywanym źródłem finansowania, leasing utrzymuje właśnie dzięki korzyściom podatkowym. Ponadto leasing jest formą finansowania, którą stosunkowo łatwiej jest uzyskać niż popularny kredyt.

Podjęte w tym artykule rozważania mają na celu przybliżenie roli i znaczenia wykorzystania leasingu w działalności i rozwoju przedsiębiorstw w Polsce na tle wybranych krajów Unii Europejskiej (UE). Na podstawie obserwacji rosnącego udziału leasingu w sektorze finansowania przedsiębiorstw można przyjąć tezę, iż polski rynek leasingu dzięki dużej dynamice rozwoju osiąga dobre wyniki na tle krajów należących do Unii.

\section{Rola i znaczenie leasingu jako źródła finasowania sprzyjającego rozwojowi przedsiębiorczości}

Jak już wcześniej wspomniano, pierwsze transakcje leasingowe zawierano już w starożytności, kiedy to w zamian za ustalaną opłatę oddawano rzeczy do ich czasowego wykorzystywania. Współczesny leasing ma jednak swój początek w Wielkiej Brytanii i Stanach Zjednoczonych, gdzie odnotowano również największy postęp w jego rozwoju.

Analizując leasing jako zjawisko ekonomiczne, można stwierdzić, iż jest on relatywnie nową metodą $\mathrm{w}$ porównaniu $\mathrm{z}$ innymi formami finansowania przedsiębiorstw. Polskie prawo ujęło pojęcie leasingu w Kodeksie cywilnym, jednak początkowo leasing funkcjonował jako umowa nienazwana i nieuregulowana w przepisach. $Z$ uwagi na brak norm regulujących szczegółowe kwestie transakcji leasingowych wątpliwości musiały być rozstrzygane przez uzgodnienia między stronami umowy, co nie zawsze przynosiło oczekiwany skutek.

Wraz z dniem 9 grudnia 2000 r. leasing stał się w Polsce umową nazwaną. Od tego momentu zaczęły bowiem obowiązywać przepisy art. 709 Kodeksu cywilnego wprowadzone do niego Ustawa z 26 lipca 2000 r. o zmianie ustawy - Kodeks cywilny. Zgodnie $\mathrm{z}$ art. 709 tego kodeksu leasing oznacza umowę, na podstawie której podmiot finansujący oddaje do użytkowania podmiotowi korzystającemu konkretny przedmiot umowy. Podmiot korzystający zobowiązuje się na mocy umowy do terminowego spłacania wartości użytkowanego przedmiotu (Ustawa $z$ dnia 26 lipca 2000 r. ...).

Kryteriami różnicującymi umowy leasingu są m.in. czas trwania umowy, obciążenia jednej ze stron kosztami związanymi z przedmiotem leasingu, liczba stron transakcji, amortyzacja wydatków związanych z zakupem przedmiotu leasingu (Bukowska-Piestrzyńska, 2003). W praktyce gospodarczej można spotkać wiele różnorodnych odmian leasingu. Klasyfikuje się go pod wieloma kategoriami, jednak wciąż jest on najbardziej rozpoznawalny jako leasing finansowy i operacyjny.

Praktyka gospodarcza wykreowała dodatkowe rozwiązanie, którym jest leasing zwrotny. Może on dotyczyć zarówno leasingu operacyjnego, jak i leasingu finansowego. Jego celami są głównie poprawa płynności finansowej przedsiębiorstwa, zamiana aktywów przedsiębiorstwa oraz uwolnienie zamrożonego kapitału bez utraty kontroli nad przedmiotem umowy. Z leasingiem zwrotnym można się spotkać, kiedy korzystający jest jednocześnie pierwotnym właścicielem przedmiotu umowy. Pierwsza część tej transakcji polega na tym, iż korzystający sprzedaje na mocy umowy sprzedaży przedmiot finansującemu. Następnym etapem jest zawarcie umowy leasingu, na podstawie której leasingobiorca (korzystający) użytkuje daną rzecz (Kalińska i in., 2018). 
Ważną cechą tego rodzaju finansowania jest także to, że nie wpływa ono na ocenę zdolności kredytowej firmy, gdyż operacja leasingowa nie jest traktowana w bilansie jako zobowiązanie. Daje też możliwość planowania kosztów na przyszłe okresy oraz stwarza preferencje podatkowe (Piecuch, 2010).

\section{Rynek usług leasingowych w Polsce}

Polscy przedsiębiorcy już od dawna chętnie sięgają po zewnętrzne źródła finansowania. Początkowa faza wykorzystywania dodatkowych środków była pełna wzrostów i spadków spowodowanych hiperinflacją. Do lat 90 . XX w. rynek leasingu bardzo powoli zyskiwał na popularności, ponieważ ograniczony był brakiem doświadczenia ze strony podmiotów gospodarczych, małą liczba firm leasingowych oraz nieuregulowanymi kwestiami prawnymi i podatkowymi. To wszystko spowodowało, iż korzystanie z niego było rzadkością (Okręglicka, 2004). Wprowadzenie mechanizmów gospodarki rynkowej miało duży wpływ na popularyzację umów leasingowych. Na początku lat 90 . zaczęło pojawiać się coraz więcej firm leasingowych, których właścicielami byli Polacy tworzący spółki z zagranicznymi udziałowcami. Zagraniczny kapitał pozwalał na zwolnienie z podatku dochodowego, dzięki czemu firmy mogły zaoferować konkurencyjne oferty. Przedsiębiorcy zaczęli przekonywać się, iż jest to stosunkowo tania, bezpieczna i wygodna metoda pozyskiwania kapitału. Początek nowej ery w rozwoju polskiego rynku leasingu dało uregulowanie pojęcia umowy leasingowej w Kodeksie cywilnym, ustawie o rachunkowości oraz w ustawach podatkowych. Był to przełom, który zażegnał m.in. sprawy sporne pomiędzy leasingobiorcami a organami podatkowymi (Cicirko, Karmańska, Russel, 2014). Przystąpienie Polski do UE w 2004 r. było kolejnym kluczowym momentem, który otworzył przed leasingiem nowe możliwości. Dobrze rozwinięte rynki leasingowe państw członkowskich pozwalały polskim przedsiębiorcom korzystać z ich doświadczeń oraz standardów.

Od ponad 25 lat polskim rynkiem leasingu zajmuje się Związek Polskiego Leasingu, który przed rokiem 2003 nosił nazwę Konferencja Przedsiębiorstw Leasingowych w Polsce. Swoją działalność dokumentuje on w postaci raportów i zestawień publikowanych kwartalnie oraz rocznie. Szczególnie ważnym raportem jest ten z 2019 r., w którym szczegółowo przedstawiono najważniejsze, decydujące wydarzenia oraz zmiany struktury i skali rynku (Związek Polskiego Leasingu, 2020). Postęp leasingu przez ostatnie 20 lat przebiegał w Polsce dość dynamicznie, co znalazło swoje udokumentowanie w liczbach.

Wśród danych przedstawionych na rycinie 1 na uwage zasługuje rok 1999, kiedy to leasing został zdefiniowany w Kodeksie cywilnym, dzięki czemu natychmiast zyskał na popularności. Kolejne trzy lata odznaczyły się niewielkim spadkiem wartości netto rynku leasingu, który to spadek został spowodowany zmieniającymi się warunkami finansowania umów przez przedsiębiorstwa bankowe. Jak wskazują dane, od 2003 r. rynek leasingu wyraźnie zaczął się rozwijać. Miało to niewątpliwie bardzo duży związek z przystąpieniem Polski do UE w 2004 r. i jednocześnie z udostępnieniem unijnego kapitału. Nadejście roku 2008, a wraz z nim światowego kryzysu gospodarczego, zostawiło swój ślad w wynikach branży leasingowej. Dynamika w tym sektorze zaczęła znacząco obniżać się już w drugiej połowie 2008 r. w większości firm leasingowych. Tendencja ta utrzymała się przez kilka lat i wyraźnie spowolniła rynek, co przełożyło się również na zahamowanie inwestycji. Przez pięć kolejnych lat rynek powoli odradzał się wraz z polską gospodarką. Za moment powrotu rynku leasingu na właściwe tory uznaje się lata 2013-2014, kiedy 
Rycina 1. Wartość polskiego rynku leasingu netto (mld zł) w latach 1999-2019

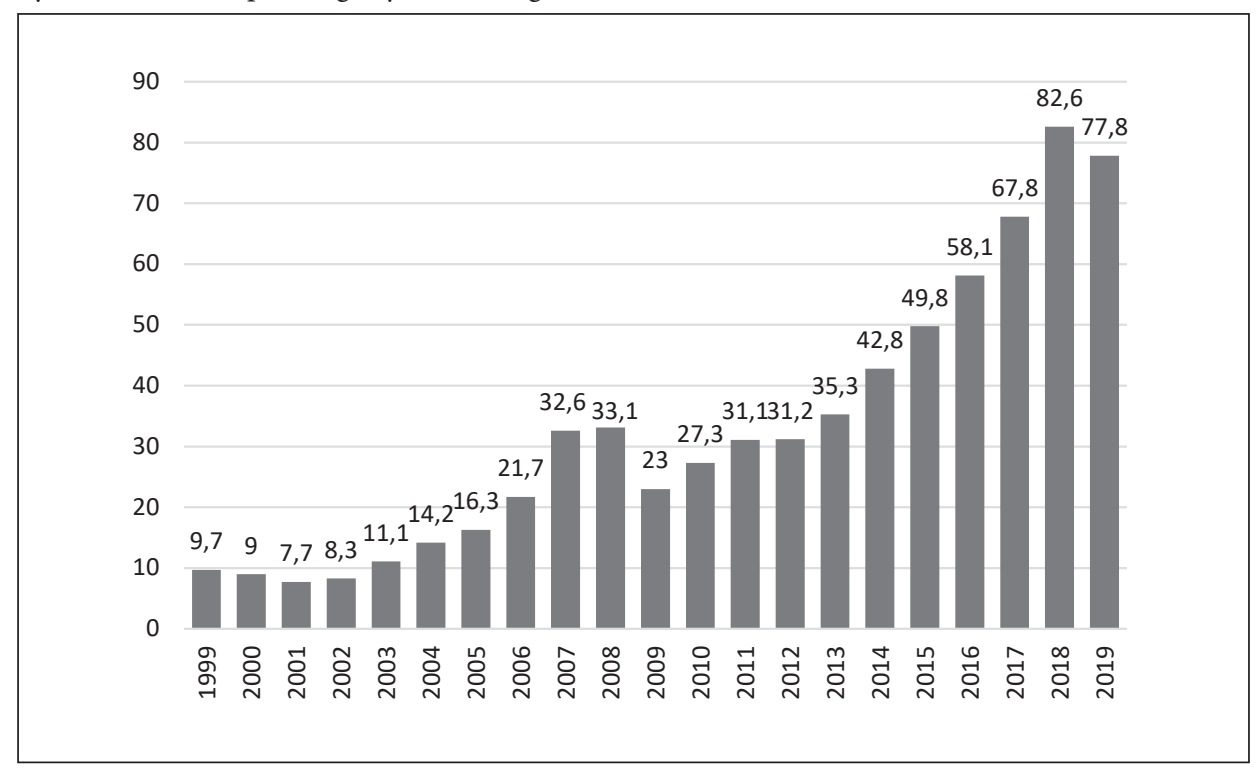

Źródło: opracowanie własne na podstawie danych ze strony: Związek Polskiego Leasingu (2020, 10 maja)

wynik netto przewyższył osiągnięcia branży sprzed światowego kryzysu (PwC, Związek Polskiego Leasingu, 2019). Zarówno rynek leasingu, jak i cała polska gospodarka w ciągu tych dwóch lat osiągnęły dobre wyniki. Głównymi siłami sprawczymi wzrostu wartości rynku leasingu były znaczny wzrost PKB w Polsce oraz zwiększona aktywność przedsiębiorstw w pozyskiwaniu kapitału (Związek Polskiego Leasingu, 2015). Wysokie tempo rozwoju utrzymywało się przez kolejne cztery lata, w czasie których średnioroczny wzrost wartości leasingu wynosił ok. 20\%. Można zatem wywnioskować, iż tak rosnący wynik branży leasingowej wynika z coraz większej liczby zawieranych transakcji i nie jest następstwem zwiększającej się wartości rynkowej przedmiotów leasingu. W 2019 r. po raz pierwszy od 10 lat rynek leasingu spotkał się z obniżeniem wartości netto w stosunku do roku poprzedniego. W 2018 r. wartość rynku osiągnęła maksimum - 82,6 mld zł i równocześnie odznaczała się bardzo wysoką dynamiką wzrostu wynoszącą $+21,8 \%$. Niestety, w ubiegłym roku przedsiębiorstwa leasingowe wykazały spadek aż o 5,8\% w odniesieniu do 2018 r. Głównym powodem pogorszenia się sytuacji na rynku leasingu w roku 2019 była zmiana przepisów o podatku dochodowym, które weszły w życie wraz z jego początkiem. Jak powszechnie wiadomo, z leasingu w większości korzystają mikro- i małe firmy, które najczęściej decydują się na finansowanie zakupu samochodów osobowych. Zmiany w przepisach podatkowych w rzeczywistości nie były spowodowane pogorszeniem się sytuacji gospodarczej naszego kraju. Był to jedynie efekt ucieczki od nowych norm prawnych przez leasingobiorców (Krupiński, 2020).

Należy zauważyć również, że branża leasingowa ma coraz większy wpływ na tworzenie PKB w Polsce, co przedstawiono na rycinie 2.

Analiza ostatnich lat polskiej gospodarki jednoznacznie wskazuje na rosnący wzrost gospodarczy. Należy tutaj wspomnieć, że razem z polską gospodarką energiczny rozwój miał miejsce również na rynku leasingu. Spadek tej tendencji odnotowany był jedynie 
Rycina 2. Udział branży leasingowej w tworzeniu PKB Polski w latach 1999-2018

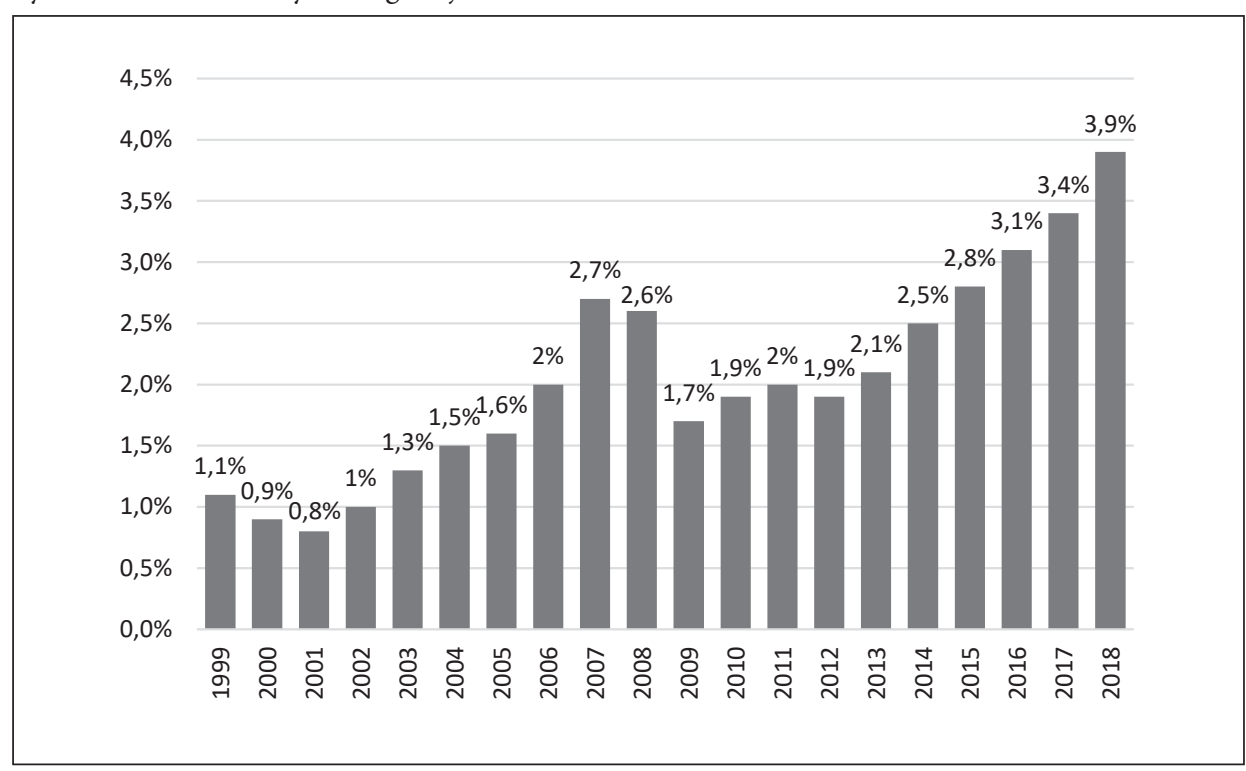

Źródło: opracowanie własne na podstawie danych ze strony: Związek Polskiego Leasingu (2020, 10 maja)

w latach odbudowy gospodarczej po kryzysie. Eksperci uważają, iż leasing w znaczącym stopniu bierze udział w tworzeniu PKB. Wspiera on polską gospodarkę na kilka sposobów. Najistotniejszy z nich to rozwój inwestycji dzięki pomocy udzielanej podmiotom z niedostateczną ilością kapitału. Leasing jest mechanizmem, który łatwo można dopasować do danego przedsiębiorstwa przez zawarcie odpowiednio elastycznej umowy. Wykorzystanie leasingu napędza rozwój technologiczny, a co za tym idzie - ma swój udział w tworzeniu nowych miejsc pracy (PwC, Związek Polskiego Leasingu, 2019). Dane dotyczące udziału leasingu w tworzeniu PKB w 2019 r. nie zostały jeszcze udokumentowane, ale w związku z ogólnym spadkiem wartości umów leasingowych spodziewany jest tożsamy spadek udziału w tworzeniu PKB. Jednak na rycinie 2 można zauważyć, iż udział leasingu w tworzeniu PKB w Polsce wzrastał i prognozowano wciąż tendencję rosnącą. Sytuacja ta może chwilowo ulec zmianie przez skutki kryzysu gospodarczego, z jakimi przyszło się zmagać gospodarce polskiej oraz światowej w związku z nastaniem pandemii COVID-19.

\section{Europejski rynek leasingu}

Aktualne dane Związku Polskiego Leasingu wskazują, iż polska i europejska gospodarka, a razem z nimi rynek leasingu już w pierwszym kwartale 2020 r. znacząco obniżyły swoje wyniki (Związek Polskiego Leasingu, 2020, 19 maja; Związek Polskiego Leasingu, 2016).

Dane Eurostatu wskazują, że w 2017 r. wartość podpisanych umów leasingu stanowiła $11 \%$ wszystkich inwestycji w UE. Nie bez powodu leasing jest nazywany europejską dźwignią inwestycji. Na rycinie 3 przedstawiono dane z 2018 r. o krajach UE, które miały największy udział na rynku leasingu i sfinansowanej przez nie wartości aktywów (PKO Leasing, 2019). 
Rycina 3. Kraje UE o największym udziale w finansowaniu leasingiem w 2019 r. (w mld euro)

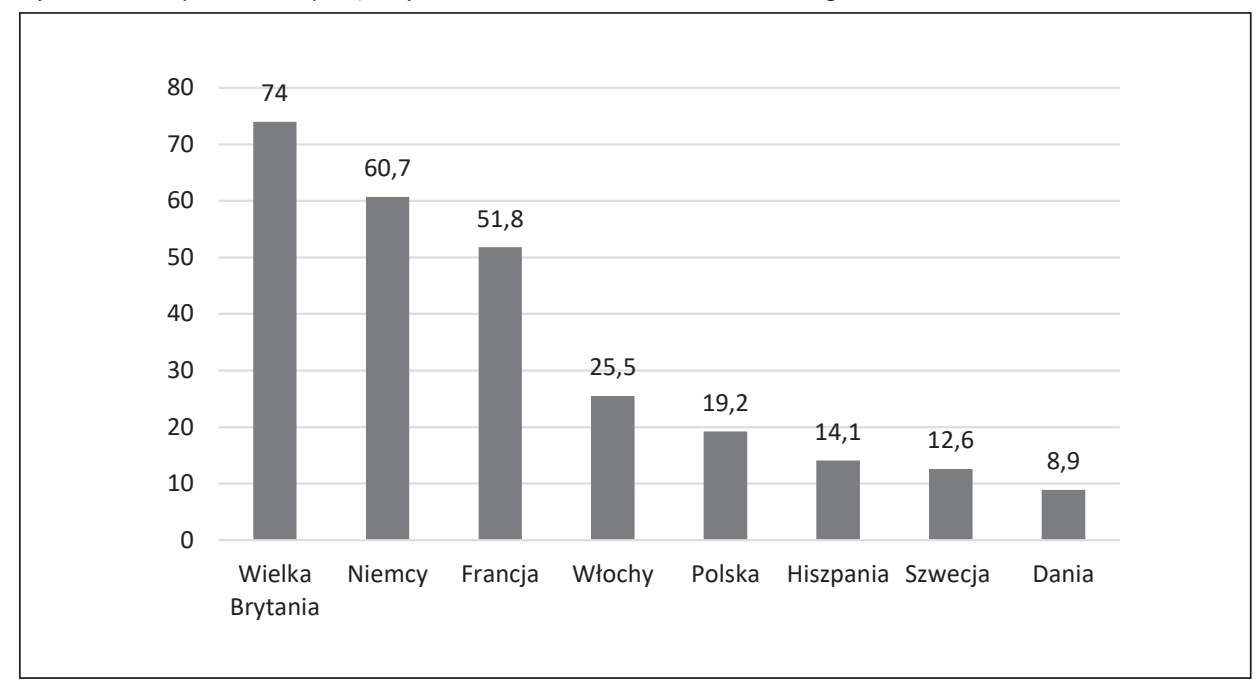

Źródło: opracowanie własne na podstawie danych ze strony: Leaseurope (2020, 29 maja)

Rycina 4. Struktura rynku leasingu w Unii Europejskiej w latach 2010, 2014, 2018

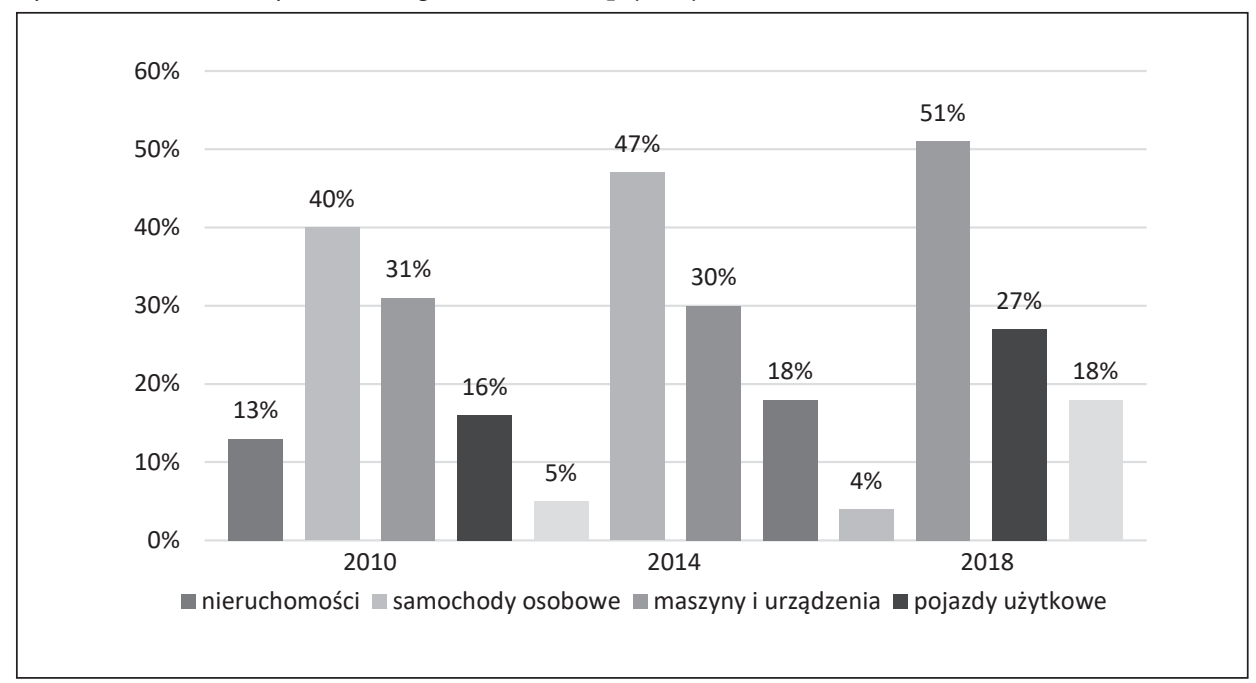

Źródło: opracowanie własne na podstawie danych ze strony: Leaseurope (2020, 29 maja)

Jak wskazują powyższe dane, w 2019 r. na pozycji lidera utrzymywała się Wielka Brytania z 74 mld euro wartości leasingu. W 2018 r. największą dynamikę wzrostu wartości nowych umów leasingu odnotowała Polska (+22\%), plasując się tym samym piątym miejscu. Najniższą wartość w finansowaniu leasingiem w grupie liderów wykazała Dnia.

Analizując wykorzystanie leasingu przez kraje UE, należy zwrócić uwagę na strukturę najczęściej finansowanych aktywów (Leaseurope, 2020, 29 maja). Na rycinie 4 porównano struktury leasingu UE w latach 2010, 2014 i 2018. 
Rynek leasingu w wybranych latach poddanych analizie należał głównie do samochodów osobowych, które w 2010 r. stanowiły 40\% aktywów sfinansowanych leasingiem. Cztery lata później ich udział zwiększył się o 7\%, a w 2018 r. stanowił już ponad połowę (51\%). Wynik ten nie jest zaskoczeniem, ponieważ samochody osobowe zdominowały rynek leasingu na całym świecie już w latach 90. Maszyny i urządzenia początkowo utrzymywały się na podobnym poziomie, ale w 2018 r. ich udział obniżył się do 27\%. Trzecie miejsce zajmują pojazdy użytkowe z ustabilizowanym wynikiem ok. 18\%. Najmniej $\mathrm{w}$ analizowanych latach w UE finansowano leasingiem nieruchomości - tu nastąpił spadek z 13\% w 2010 r. do zaledwie 4\% w 2018 r. Struktura UE w dużym stopniu przypomina polską strukturę rynku leasingu, gdzie również nieruchomości stanowią zaledwie kilka procent udziału. Z odbiorcami usług finansowych zazwyczaj kojarzone są podmioty gospodarcze sektora usług oraz przemysłu i budownictwa. Jednak mogą być nimi zarówno podmioty gospodarcze, jak i osoby fizyczne nieprowadzące działalności gospodarczej.

\section{Prognozy tendencji rozwoju leasingu w Polsce i Europie}

W 2019 r. polska gospodarka przeżyła łagodne spowolnienie tempa rozwoju, co odczuł również sektor polskiego leasingu. W ostatnim roku dynamicznie rozwijał się portfel aktywnych umów sektora leasingowego. Wartość aktualnie trwających kontraktów branży jest o 9,4\% wyższa niż przed rokiem. Dynamika nowych kontraktów podpisanych przez firmy leasingowe w ostatnim roku była jednak ujemna - obniżyła się o 5,8\%. W 2019 r. Polska odnotowała łagodne hamowanie tempa rozwoju gospodarki, co w naturalny sposób odczuła także branża leasingowa. Na początku 2020 r. prognozowano powrót na ścieżkę wzrostów, wynikający z wysokiego popytu krajowego. Badania Komisji Europejskiej pokazują, że leasing pozostaje najistotniejszym źródłem finansowania dla 63\% małych i średnich firm działających w Polsce, a odsetek deklarujących to firm zwiększył się o 9\% w ciągu ostatnich sześciu lat (Związek Polskiego Leasingu, 2020).

Przedstawione prognozy opierają się na informacji, według której w Polsce w 2020 r. ma nastąpić wzrost liczby prywatnych inwestycji oraz ogólny wzrost gospodarczy kraju. Związek Polskiego Leasingu największego wzrostu spodziewa się nadal w kategorii pojazdów samochodowych. Szacuje się, iż wzrost ten będzie się kształtował na poziomie ok. 8\%. Leasing komputerów i sprzętu IT ma zapisać się wzrostem o ok. 6,8\%. Unia Europejska zaplanowała na 2020 r. zmiany, które niekorzystnie wpłynęły i wpłyną na polskie firmy transportowe. Chodzi tutaj o pakiet mobilności oraz nowe przepisy dotyczące pracowników delegowanych.

Odnosząc się do zeszłorocznych danych oraz danych z roku 2018, przewidywana była dalsza ścieżka wzrostu rynku europejskiego leasingu. Jednak pandemia COVID-19 jest niewątpliwie poważnym wyzwaniem w każdej dziedzinie gospodarczej. Okazało się bowiem, że leasingobiorcy od momentu ogłoszenia pierwszego przypadku zachorowania w Polsce zaczęli masowo rezygnować z rozpoczętych już rozmów na temat leasingu oraz wycofywać wnioski. Duża część korzystających z leasingu musiała nagle zawiesić swoją działalność gospodarczą. Według tych danych, marzec $2020 \mathrm{w}$ porównaniu z marcem 2019 zapisał się blisko 32-procentowym spadkiem wartości rynku leasingu. Jednak był to miesiąc, w którym pandemia dopiero wkraczała do naszego kraju i gospodarka nie była jeszcze zbyt obciążona. Dane za miesiąc kwiecień ukazały, że w porównaniu z rokiem 2019 rynek leasingu skurczył się o prawie 50\%, z czego największy spadek dotyczył 
środków transportu. Przedstawiciele ZPL twierdzą, iż rynek leasingu odnotuje podobny kryzys jak w przypadku historycznego kryzysu globalnego z 2008 r. Stąd też odbudowa załamania, z którym prawdopodobnie przyjdzie się zmierzyć polskiej gospodarce, może potrwać dłużej niż przy poprzednim kryzysie. Jako powód można przywołać spadek zaufania leasingobiorców do stabilnej dotychczas gospodarki oraz dłuższą perspektywę planowania, a co za tym idzie - ostrożność w podejmowaniu decyzji długoterminowych (Związek Polskiego Leasingu, 2020, 19 maja).

\section{Podsumowanie}

Na podstawie przeprowadzonych analiz można stwierdzić, że bardzo wysoka pozycja Polski w rankingu UE - zaraz za największymi potęgami gospodarczymi Europy - wskazuje, iż nasz kraj odgrywa doniosłą rolę w kształtowaniu statystyk europejskiego rynku leasingu. Finansowanie inwestycji za pomocą leasingu w Polsce na przełomie ostatnich 20 lat niewątpliwie zyskało na wartości oraz popularności, o czym świadczy blisko 88-procentowy wzrost wartości branży leasingowej w Polsce od roku 1999 do 2019. Jednocześnie tak wysoka dynamika wzrostu polskiego rynku leasingu została odnotowana już w 2013 r., kiedy to Polska znalazła się wśród 10 najwyżej notowanych państw na europejskim rynku leasingu. Historyczny rok 2019 zapisał się dla Polski rekordowym piątym miejscem w rankingu liderów europejskiego rynku leasingu. Potwierdza to stwierdzenie o niewątpliwie szybkim i efektywnym rozwoju polskiej branży. Zestawienie struktur rynku leasingu ruchomości pozwala stwierdzić, iż zarówno w 2010, jak i w 2019 r. największy udział w obu tych kategoriach miały środki transportu drogowego. Zbieżność wyników jest zauważalna na rynku europejskim, gdzie samochody osobowe i pojazdy użytkowe stanowią największy procent leasingowanych przedmiotów. Zmiana nastąpiła na rynku nieruchomości, gdzie w 2010 r. największą popularnością cieszyły się budynki przemysłowe, natomiast obecnie zważywszy na przemiany struktury przedsiębiorstw w naszym kraju pierwsze miejsce zajmują obiekty biurowe. Jednakże udział całościowy rynku nieruchomości jest nadal znikomy. W Polsce i w UE nie przekracza on nawet $4 \%$. Różnica w obu rynkach dostrzegalna jest w strukturze odbiorców usług leasingowych. Ponieważ w Polsce najpopularniejszymi odbiorcami są poszukujący źródeł finansowania i atrakcyjnych ofert przedstawiciele podmiotów gospodarczych, to konsumenci prywatni oraz sektor publiczny są wręcz niezauważalni w zestawieniu odbiorców. Natomiast w strukturze odbiorców UE konsumenci prywatni stanowią blisko jedną piątą, a sektor publiczny - ok. $4 \%$.

Rosnąca pozycja Polski oraz uplasowanie się wśród światowych przodowników gospodarczych jest niebywałym sukcesem naszej branży leasingowej. Polska, podobnie jak kraje UE, niejednokrotnie miała do czynienia z problemami gospodarczymi, z których największym był światowy kryzys gospodarczy. Podobnie jak światowi triumfatorzy nasz kraj relatywnie szybko się po nim podniósł. Porównując ówczesną sytuację gospodarczą liderów z sytuacją gospodarczą w Polsce i biorąc pod uwagę wielkość naszego kraju, postęp i dynamikę wzrostu gospodarczego, można powiedzieć, że Polska niepodważalnie im dorównuje. Kolejną próbą, która dosięgnie globalnego rynku leasingu oraz całą światową gospodarkę, jest zmierzenie się ze skutkami pandemii COVID-19. Eksperci już odnotowują oraz przewidują dalsze pogorszenie się wyników gospodarczych, porównywalne lub większe niż miało to miejsce w latach 2008-2009. 
Przeprowadzona analiza porównawcza wykorzystania leasingu w Polsce oraz UE pozwala stwierdzić, że korzyści wynikające z finansowania działalności gospodarczej leasingiem sprawiły, iż na tę formę pozyskania kapitału decyduje się coraz większa liczba podmiotów zarówno w naszym kraju, jak i w całej UE. Największą grupą odbiorców na rynku leasingu są mikroprzedsiębiorcy oraz sektor usługowy. Z kolei dynamika wzrostu polskiej branży leasingowej stanowi bardzo duży udział w dynamice wzrostu rynku europejskiego.

Sytuacja związana z pandemią chociaż aktualnie powoduje spadki w branży leasingowej, to w przyszłości może być konsekwencją zwiększenia popytu na usługi leasingowe. Wynikać to może z tego, iż przedsiębiorcy pozbawieni przez czas kryzysu zapasów kapitałowych, będą poszukiwali alternatywnych źródeł finansowania, które będą łatwo dostępne, stosunkowo mniej ryzykowne i przyniosą w przyszłości korzyści finansowe dla przedsiębiorstwa i jego rozwoju. W ten sposób wybór leasingu jako źródła finansowania działalności gospodarczej przyczyni się do poprawy sytuacji finansowej oraz do ogólnego rozwoju działalności gospodarczej przedsiębiorstw.

Literatura

References

Bobrowski, S. (2020, 27 maja). Leasing samochodu w podatku VAT po 1 kwietnia 2014 r. Pozyskano z: http://www.podatki.egospodarka.pl/107316,Leasing-samochodu-w-podatku-VAT-po-1-kwietnia-2014-r,1,68,1.html

Bukowska-Piestrzyńska, A. (2003). Leasing. Istota, uwarunkowania, funkcjonowanie. Łódź: Wydawnictwo Wyższej Szkoły Finansów i Informatyki.

Cicirko, T., Karmańska, A., Russel, P. (2014). Determinanty rozwoju transakcji leasingowych $w$ Polsce. Warszawa: Oficyna Wydawnicza SGH.

Kalińska, E., Pacanowska-Stasiak, A., Diering, T., Filipowski, K., Barański, J., Sporny M., Wolnowska, E. (2018). Poradnik prenumeratora. Leasing 2018. Warszawa: Wydawnictwo Gremi Media.

Korczyn, A. (2015). Leasing na nowych zasadach. Aspekt prawny, podatkowy i ksiegowy. Skierniewice: Wydawnictwo Sigma.

Krupiński, M. (2020). Rynek leasingu w 2019 roku. Miał być wzrost, jest spadek. Pozyskano z: https:// www.fmleasing.pl/aktualnosci/rynek-leasingu-2019

Lazarowicz, A. (2013; 2020, 27 maja). Zmiany w leasingu 2013. Pozyskano z: https://poradnikprzedsiebiorcy.pl/-zmiany-w-leasingu-2013

Leaseurope. (2020, 29 maja). http://www.leaseurope.org

Okręglicka, M. (2004). Leasing. Aspekty prawne, organizacyjne i ekonomiczne. Warszawa: Difin.

Piecuch, T. (2010). Przedsiębiorczość: podstawy teoretyczne. Warszawa: Wydawnictwo C.H. Beck.

PKO Leasing. (2019). Raport specjalny: Znaczenie rynku leasingu w gospodarce europejskiej. Pozyskano z: https://www.pkoleasing.pl/media_files/be97ac8e-9cce-4b7d-b14e-7781536d9d89.pdf

PwC, Związek Polskiego Leasingu. (2019). 25 lat leasingu w Polsce. Od finansowej innowacji do finansowania polskiej innowacyjności. Warszawa. Pozyskano z: http://leasing.org.pl/files/uploaded/ ZPL\%20Raport_Final.pdf

Rynek leasingu w Polsce w 2020 r. wzrośnie o 6,3 proc. - ZPL. (2020, 29 maja). Pozyskano z: https://strefainwestorow.pl/wiadomosci/20200204/rynek-leasingu-w-polsce-w-2020-r-wzrosnie-o-63-proc-zpl

Ustawa z dnia 26 lipca 2000 r. o zmianie ustawy - Kodeks cywilny. Dz.U. nr 74, poz. 857 z późn. zm.

Ustawa z dnia 23 kwietnia 1964 r. Kodeks cywilny. Dz.U. z 2019 r., poz. 1145.

Ustawa $z$ dnia 15 lutego 1992 r. o podatku dochodowym od osób prawnych. Dz.U.2019.0.865.

Ustawa z dnia 26 lipca 1991 r. o podatku dochodowym od osób fizycznych. Dz.U.2019.0.1387. 
Związek Polskiego Leasingu. (2020). Wyniki branży leasingowej za 2019 rok. Warszawa.

Związek Polskiego Leasingu. (2020, 19 maja). Leasing hamuje od poczatku roku. Pozyskano z: http:// leasing.org.pl/pl/aktualnosci/2020/leasing-hamuje-od-poczatku-roku

Związek Polskiego Leasingu. (2020, 10 maja). http://www.leasing.org.pl

Związek Polskiego Leasingu. (2016). Wyniki branży leasingowej za 2015 rok. Warszawa.

Związek Polskiego Leasingu. (2015). Wyniki branży leasingowej za 2014 rok. Warszawa. Pozyskano z: http://www.outsourcingportal.eu/pl/userfiles/image/raporty/2015/2/2/Wyniki_brany_leasingowej_za_2014_rok_02.02.2015.pdf

Renata Nesterowicz, dr nauk ekonomicznych, adunkt. Uniwersytet Rzeszowski, Kolegium Nauk Społecznych, Instytut Ekonomii i Finansów, Katedra Finansów i Rachunkowości. Autorka licznych publikacji z zakresu finansów i rachunkowości. Jej zainteresowania naukowe to ocena wyników i dokonań małych i średnich przedsiębiorstw w Polsce.

Renata Nesterowicz, PhD in Economics, assistant professor at the University of Rzeszów, College of Social Sciences, Institute of Economics and Finances, Department of Finances and Accounting. The author of numerous publications on finances and accounting. Her research interest is the evaluation of results and effects of small and medium-sized enterprises in Poland.

ORCID: https://orcid.org/0000-0002-0254-9633

\section{Adres/Address:}

Uniwersytet Rzeszowski

Instytut Ekonomii i Finansów

Katedra Finansów i Rachunkowości

ul. Ćwiklińskiej 2a, p. 201

35-959 Rzeszów, Poland

e-mail: rbnester@onet.eu

Aleksandra Nesterowicz, studentka, Uniwersytet Rzeszowski, Kolegium Nauk Ekonomicznych, Instytut Ekonomii i Finansów, II rok I stopień, specjalność: ekonomia usług biznesowych.

\section{Adres/Address:}

Uniwersytet Rzeszowski

Instytut Ekonomii i Finansów

Katedra Finansów i Rachunkowości

ul. Ćwiklińskiej 2a, p. 201

35-959 Rzeszów, Poland

e-mail: aleksandra.nesterowicz@onet.pl 